\section{Wojciech Ryczek}

Uniwersytet Jagielloński

\title{
Parezja: ćwiczenia ze szczerości
}

\section{Abstract \\ Parrhesia: Exercises in Speaking Sincerely}

The paper examines the notion of parrhesia (from Greek 'to speak everything') as an exercise in speaking openly and sincerely. Leaving aside Michel Foucault's treatment of this discursive activity, the main purpose of the article is to describe parrhesia in three domains: rhetoric, philosophy, and literature. As a figure of speech, it remains closely associated with rhetorical simulation and flattery. For many rhetoricians, for instance Quintilian or Jakub Górski, parrhesia may serve as a useful instrument of critical speaking. As a "spiritual exercise" in telling the truth, it plays an important role in transforming philosophy into a general way of life. In accordance with Philodemus's beliefs on frank speech, one may argue that parrhesia helps in attaining wisdom in a student milieu. And finally, as a discursive strategy, it creates many possibilities for expanding the modes of linguistic expression, for instance in Horace's ode to Virgil (Carmina I 24) or in Maciej Kazimierz Sarbiewski's ode to Publius Munatius (Lyrica III 5). In both texts, parrhesia is involved in the discourse of friendship.

Słowa kluczowe: parezja, retoryka, figury, Filodemos, Horacy, Maciej Kazimierz Sarbiewski (Sarbievius)

Keywords: parrhesia, rhetoric, figures, Philodemus, Horace, Maciej Kazimierz Sarbiewski (Sarbievius)

Pojęcie parezji, mowy otwartej i swobodnej, zostało we współczesnym dyskursie humanistycznym niemal całkowicie sprywatyzowane przez Michela 
Foucaulta ${ }^{1}$. W przywróceniu zainteresowania ideą wolności przemawiania odegrał on niewątpliwie dużą rolę, przesłaniając zaproponowaną interpretacją wiele wątków bogatej tradycji tego pojęcia, które nie mieściły się w nowym projekcie filozoficznym spod znaku "troski o siebie" (epimeleia heautou, le souci de soi) i „odwagi prawdy” (le courage de la vérité) ${ }^{2}$. Nie można zapominać, że parezja była owocem kultury greckiej, zrodzonym w określonych warunkach historycznych (rzeczywistość ateńskiej polis). Szybko znalazła swe miejsce w przestrzeni politycznej, filozofii i retoryce. Zagościła na agorze (później na rzymskim forum), a także w szkołach prowadzonych przez miłośników mądrości i retorów. Przemówiła najpełniej w nauczaniu i postawie Sokratesa, czyniąc z bezkompromisowego mędrca o enigmatycznej naturze (atopia) uniwersalną figurę prawdziwego parezjasty. Wszędzie stanowiła zachętę do rozważań nad naturą wolności, retorycznymi mechanizmami szczerości, ciągłym poszerzaniem swobody mówienia w ramach istniejących ograniczeń (nie tylko zresztą instytucjonalnych), prawdomównością, wiarą w głoszone publicznie idee, wartością krytycznego myślenia czy etycznymi zobowiązaniami.

Kiedy „późny” Foucault, zwracający się coraz częściej w stronę filozofii jako modelu egzystencji, odkrywał znaczenia parezji, była ona już od wielu lat przedmiotem studiów biblijnych (Giuseppe Scarpat, Stanley Marrow) ${ }^{3}$. Wystarczy przypomnieć, że deklaracja wyboru prostego, otwartego sposobu mówienia jest ważnym elementem retorycznej autoprezentacji św. Pawła jako miłośnika prawdy i prostoty wysłowienia, zainteresowanego wyłącznie głoszeniem Ewangelii. U francuskiego myśliciela rekonstrukcja historii tej idei, wolna od antykwarycznego skostnienia, prowadzi do interpretacji pozwalającej włączyć mowę swobodną, eksponującą przywiązanie autora do prawdy (ściślej: mówienia prawdy), w nowy porządek pojęć skupionych wokół pielęgnowania siebie. Jako „hermeneutyka podmiotu” parezja ma być „niezależna od reguł i procedur retorycznych"4, aby jeszcze wyraźniej podkreślać zobo-

1 Zob. M. Foucault, Fearless Speech, ed. J. Pearson, Los Angeles 2001 (zapis wykładów wygłoszonych w październiku 1983 roku w Berkeley); idem, Hermeneutyka podmiotu, przeł. M. Herer, Warszawa 2012; idem, Rzadzenie soba i innymi, przeł. M. Herer, Warszawa 2014; idem, Le courage de la vérité. Le gouvernement de soi et des autres II. Cours au Collège de France 1984, Paris 2008.

2 Zob. M. Kwiek, W stronę estetyki egzystencji: Michel Foucault [w:] idem, Dylematy tożsamości. Wokót autowizerunku w powojennej myśli francuskiej, Poznań 1999, s. 266312; T. Dyrberg, Foucault on the Politics of Parrhesia, New York 2014.

3 G. Scarpat, Parrhesia. Storia del termine e delle sue traduzione in latino, Brescia 1964; idem, Parrhesia greca, parrhesia cristiana, Brescia 2001. Zob. S.B. Marrow SJ, Parrhesia and the New Testament, „Catholic Biblical Quarterly” 1982, vol. 44, s. 431-446.

4 M. Foucault, Hermeneutyka podmiotu, s. 395. 
wiązanie mówiącego do życia w zgodzie z głoszonymi naukami. Od samego początku bierze ona udział w tworzeniu obrazu mówcy jako osoby zdającej dokładną, szczerą relację ze swoich myśli i doświadczeń.

Pozostawiając na boku koncepcje filozoficzne Foucaulta, proponuję potraktować szeroko rozumianą parezję jako rodzaj ćwiczenia ze szczerości, pozwalającego poszerzać przestrzeń swobody mówienia i tworzyć wrażenie spontaniczności wypowiedzi. Krótkie omówienie dwóch tradycji myślenia o tej strategii (retorycznej i filozoficznej) na podstawie zaleceń Kwintyliana, Jakuba Górskiego i Filodemosa umożliwi wykorzystanie jej w interpretacji dwóch tekstów literackich - pieśni Horacego adresowanej do Wergiliusza (Carmina I 24) i ody Macieja Kazimierza Sarbiewskiego skierowanej do Publiusza Munacjusza (Lyrica III 5). W obu utworach problematyka mowy swobodnej łączy się bezpośrednio z kwestią przyjaźni, a literatura okazuje się miejscem eksperymentowania z różnymi strategiami parezjastycznymi. Moim celem nie jest rekonstrukcja długiej historii parezji, lecz prezentacja wybranych form i formuł, jakie najczęściej przybierała w praktyce językowej. Korzystając z pewnej swobody inwencyjnej, zestawiam autorów z XVI i XVII wieku z ich antycznymi mistrzami (na przykład Kwintyliana i Jakuba Górskiego), aby ukazać przemiany w myśleniu o istocie oraz funkcjach idei mowy szczerej i otwartej.

W sztuce wymowy parezja (z greckiego parrhesia - „powiedzieć wszystko”) stanowi swego rodzaju licencję retoryczną ${ }^{5}$, mającą wiele miejsc wspólnych z dobrze znaną licencją poetycką, pełną swobodą twórczą w zakresie korzystania z reguł inwencji i elokucji, a także ich przetwarzania i wynajdywania za każdym razem niejako na nowo. Najpełniejsze ujęcie teoretyczne tej figury pozostawił Kwintylian (Institutio oratoria, IX 2, 26-27) 6 , wspominając o schematach wysłowienia służących przede wszystkim wzmacnianiu oddziaływania emocjonalnego. Świadomie i z rozmysłem mówca sięga po symulację artystyczną (udawanie) za każdym razem, gdy podczas przemowy daje wy-

5 Zob. H. Lausberg, Retoryka literacka. Podstawy wiedzy o literaturze, przeł. i oprac. A. Gorzkowski, Bydgoszcz 2002, s. 419-420.

6 Zob. D. Parkin-Speer, Freedom of Speech in Sixteenth Century English Literature, „Sixteenth Century Journal” 1981, vol. 3, s. 66-67; D. Colclough, Parrhesia: The Rhetoric of Free Speech in Early Modern England, „Rhetorica” 1999, no. 2, s. 186; idem, Freedom of Speech in Early Stuart England, Cambridge 2005, s. 34-35; W. Ryczek, Libertas dicendi. Z genealogii pojęcia parezji, „Teksty Drugie” 2012, nr 3, s. 106-108; idem, Speaking Freely: Keckermann on the Figure of Parrhesia, „Rhetorica” 2019, no. 2, s. 175-178. 
raz radości, zdziwieniu, zachwytowi czy oburzeniu. Podobnie - jak zaznacza rzymski retor - działa parezja, „mowa swobodna” (oratio libera), oznaczająca przejście, często sygnalizowane przez autora za pomocą odpowiednich formuł językowych, do innego sposobu mówienia, „bardziej szczerego”, otwartego, tymczasowo uwolnionego od sztywnych regulacji sztuki wymowy.

Lakoniczna uwaga Kwintyliana dotycząca parezji, wpleciona w długie wyliczenie rozmaitych figur retorycznych, odsłania charakterystyczne dla całej retoryki uwikłanie w niedające się pogodzić (nawet retorycznie) antynomie: autentyczności i symulacji, językowej naturalności i artystycznej „,sztuczności”, natury i sztuki, prawdy i estetycznego pozoru. Bliskie sąsiedztwo parezji z figurami służącymi wzbudzaniu bądź wyrażaniu afektów przyczyniło się do uznania tej formy retorycznej za odmianę wykrzyknienia (exclamatio), najbardziej wyrazistego przejawu emocjonalnego zaangażowania mówcy?. Kwintylian zwraca jednak uwagę na podobieństwo, nie zaś na identyczność. „Mowa swobodna” przypomina działanie figur odpowiedzialnych za ekspresję uczuć pod względem ich zależności od artystycznego opracowania. Mówiąc inaczej, figuratywność jako określony sposób użycia języka zakłada symulację (udawanie) regulowaną przepisami sztuki wymowy. Rozmaite uzewnętrznione językowo uczucia stają się figurami dopiero wtedy, gdy są rezultatem retorycznej kalkulacji, sporządzonej dużo wcześniej na potrzeby skutecznego przekonywania. Ta prawidłowość dotyczy także parezji jako poszukiwania swobody mówienia w granicach wyznaczonych przez reguły elokucji. Albo jeszcze inaczej: nieustannego poszerzania przestrzeni wolności słowa w obrębie samej wymowy, negocjowania czy kwestionowania normy retorycznej. Dlatego rozważania Kwintyliana zamyka pytanie wykraczające daleko poza szczegółowe kwestie związane ze skuteczną perswazją: „,cóż bowiem jest mniej figuratywne od prawdziwej wolności? (quid enim minus figuratum quam vera libertas?)"".

Kwintylian zdawał sobie doskonale sprawę z niemożności wtłoczenia swobodnej, spontanicznej mowy w sztywne schematy wysłowienia. Jako nauczyciel wymowy był zainteresowany przystępnym wykładem reguł retorycznych. Przyjęte przez niego kryterium prawdziwości i symulacji (udawania) ustanawia jednak niewyraźną i płynną granicę między naturalną szczerością a zaplanowaną wcześniej strategią retoryczną. Jak w soczewce skupiają się w parezji pytania o naturę figuratywności, o istotę tropu i figury, o granice językowe wytyczane przez różne sposoby mówienia. „Prawdziwa” wolność, obywająca się często bez konieczności artykulacji językowej, wymyka się skutecznie wszelkim regulacjom sztuki. Wyzwolona spod władzy wymowy, nie

7 Taką redukcjonistyczną interpretację figury otwartości mówienia proponował m.in. M. Foucault, Fearless Speech, s. 21.

${ }^{8}$ Kwintylian, Institutio oratoria, IX 2, 27 [w:] The Institutio oratoria of Quintilian, ed. H.E. Butler, t. 3, Harvard 1976, s. 388. Wszystkie tłumaczenie pochodzą ode mnie. 
traci bynajmniej potencjału perswazyjnego. Jako postawa eksponująca etos mówcy afirmującego niezależność od zewnętrznych uwarunkowań i wierność swoim przekonaniom może przekonywać o wiele bardziej niż dopracowana retorycznie mowa. W tym kontekście parezja jako figura stanowi ekspresję wolności mówienia, koncesjonowanej wprawdzie przez reguły elokucji, lecz ciągle poszerzanej dzięki inwencji mówcy skoncentrowanej wokół kształtowania materii językowej.

Parezja może czasem, zdaniem Kwintyliana, wiązać się z wyrażonym mniej lub bardziej bezpośrednio pochlebstwem (adulatio), zwłaszcza wtedy, gdy służy krytyce wymierzonej przeciw konkretnemu adresatowi. W takiej sytuacji mówca, aby nie zrazić do siebie odbiorców, stara się im wcześniej przypodobać. Słodycz pochlebstwa łagodzi wówczas gorycz nieprzyjemnej prawdy. Odpowiednio dobrane i wyważone słowa pozwalają powiedzieć znacznie więcej, w bardziej otwarty sposób, nawet wtedy, gdy zwracamy się do władcy, mistrza, nauczyciela czy przełożonego. Licencja retoryczna, stanowiąca podstawę kontraktu parezjastycznego zawieranego między mówiącym a odbiorcami, pozwala zapanować nad gwałtownym przypływem szczerości. Działa niczym zwrotnica umożliwiająca szybkie przestawienie dyskursu na nowe tory. Jako strategia krytyczna stanowi splot wielu predyspozycji i kompetencji retorycznych: odwagi w zabieraniu głosu, gotowości do podjęcia ryzyka, śmiałości w wydawaniu sądów, wreszcie - pragnienia prawdomówności.

Wiele miejsca poświęcił parezji Jakub Górski (ok. 1525-1585), długoletni nauczyciel retoryki i dialektyki w Akademii Krakowskiej, w podręczniku O figurach gramatycznych i retorycznych (De figuris tum grammaticis, tum rhetoricis):

Licencja pojawia się wtedy, gdy mówimy na mocy naszego prawa [do swobody wypowiedzi - dop. W.R.] do tych, których powinniśmy szanować albo się obawiać jednak tak, aby nie urazić ich ani bliskich im osób, gdy wydaje się nam, że możemy słusznie ich ganić za jakiś błąd. Powinniśmy mieć bowiem w tej figurze wzgląd na dwa rodzaje osób, po pierwsze na tych, których powinniśmy szanować z powodu znaczenia czy cnoty albo obawiać się z powodu władzy, po drugie na tych, których oni miłują i szanują z powodu znaczenia, władzy czy obu tych rzeczy; nie można ich ganić bez urażenia tamtych i dlatego trzeba korzystać z parezji ostrożnie i tak ganić oba rodzaje osób, aby nie doszło do żadnej urazy ${ }^{9}$.

9 I. Gorscius, De figuris tum grammaticis, tum rhetoricis libri quinque nunc recens aediti, Cracoviae: in officina typographica Matthaei Siebeneycher, 1560, s. 278-279: „Est enim licentia, cum apud eos, quos aut vereri aut metuere debemus, tamen pro iure nostro dicimus, quod eos minime offendat aut quos ii diligunt, cum in aliquo errato vere reprehendi posse videantur. Duo enim genera personarum in hac figura spectare debemus, primum eorum, quos aut reveri debemus propter autoritatem et virtutem aut metuere propter potentiam, alterum eorum, quos illi qui vel auctoritate vel potentia vel utroque praediti sunt 
Górski wyróżnił dwa rodzaje mowy swobodnej, uważanej za odmianę figury emocjonalnego zaangażowania (pathopoeia). Pierwszy dotyczy parezji „prawdziwej”, gdy mówca występuje otwarcie przeciw konkretnym wadom i błędom, domagając się zmiany czy poprawy. W drugim przypadku mamy do czynienia z parezją ,udawaną", kiedy korzysta on z pochlebstwa, aby móc powiedzieć znacznie więcej. Autor przywołuje obficie cytaty z mów Cycerona wymierzonych w Marka Antoniusza, w których licencja retoryczna sprzymierzona $\mathrm{z}$ różnymi odmianami tropu ironicznego służyła zarówno afirmacji etosu obywatela zatroskanego o dobro państwa, jak i nieustępliwej krytyce skorumpowanych etycznie polityków i wodzów wojskowych. Świadczą o tym następujące słowa Arpinaty:

[...] wy bowiem ojcowie (ciężko o tym mówić, lecz trzeba to powiedzieć), wy pozbawiliście życia Serwiusza Sulpicjusza. Widzieliście, że nie wymawia się bardziej chorobą niż mową. Nie byliście wprawdzie okrutni; czyż jest bowiem coś, co mniej przystoi temu stanowi? Zbyt gwałtownie sprzeciwiliście się jego odmowie, mając nadzieję, że nie zdarzy się nic, czemu nie mógłby sprostać swą powagą i mądrością. Kogoś, kto miał zawsze wasze zdanie w największym poważaniu, zmusiliście, aby odstąpił od swego zdania (Philippica IX 4, 8).

Z nieskrywanym podziwem dla parezjastycznej aktywności Cycerona przywołuje Górski i pokrótce omawia poszczególne fragmenty z jego mów. Zdaniem autora, Cyceron ucieleśniał wszelkie cnoty retoryczne; pod względem sztuki inwencji i elokucji nie miał sobie równych, dlatego mógł również występować w roli mistrza i nauczyciela parezji. Jak przypominał humanista, jeśli mowa swobodna pozwala mówić rzeczy nieprzyjemne dla odbiorców, trzeba wprowadzić ją czasami umiejętnie za pomocą odpowiednich formuł typu: „ciężko o tym mówić, lecz trzeba to powiedzieć”, „nie można mówić o tym bez wstydu”, ,przykre są te słowa, lecz prawdziwe”. Z tego powodu zanim Cyceron zwrócił ostrze krytyki przeciw senatorom, czyniąc ich odpowiedzialnymi za śmierć wybitnego wodza (wspomnianego wcześniej Sulpicjusza), wyraźnie zaznaczył swoje zobowiązanie wobec mówienia prawdy o instytucji stojącej na straży wolności. Jeśli mówca, jak powiada Górski, zadaje „rany duszom słuchaczy, musi przynieść im natychmiast lekarstwo"10.

amant et colunt, qui reprehendi non possunt sine illorum offensione utendum itaque licentia caute est et ita reprehendendum utrumque genus, ut nulla inde offensio sequatur". Górski powtórzył definicję parezji z traktatu Retoryka dla Herenniusza (IV 48), przypisywanego przez długi czas Cyceronowi.

10 Ibidem, s. 280: „Ita cum alibi tum hic quoque medela opus est, liberior orator vulnerat saepe animos auditorum, quibus medicina statim adhibenda, ne exulcerati infestiores nobis sint". 
Niezależnie od tego, czy uznajemy parezję za odmianę wykrzyknienia, czy w pełni autonomiczną formę językową, czy też jedną z wielu figur oddziaływania na emocje odbiorców, ma ona znaczący udział w autoprezentacji mówcy. Jako parezjasta daje się on poznać słuchaczom dzięki wyborom (także retorycznym), jakich nieustannie dokonuje, rozwijając argumentację czy występując przeciw błędom. Jego credo mogą stanowić słynne słowa Cycerona:

[...] cóż, czy mogę mówić o pozostałych nieszczęściach rzeczypospolitej? Zawsze będzie mi wolno bronić godności, gardzić śmiercią. Obym miał tylko prawo przychodzenia tutaj, a nie będę unikać niebezpieczeństwa związanego z przemawianiem (Philippica I 14).

Mówca sięgający po parezję podkreśla swe głębokie przywiązanie do szeroko rozumianej wolności i intelektualnej niezależności. Za każdym razem liczy się z niebezpieczeństwem (nawet ryzykiem śmierci), jakie podejmuje, zabierając otwarcie głos, gdyż brak możliwości swobodnego mówienia uznaje za największe zagrożenie dla wolności. Nie bez powodu synonimami parezji jako formy retorycznej mogą być szczerość, otwartość, śmiałość i odwaga. Parezjasta nie tylko wierzy w sprawczą moc słowa, lecz także przedstawia się jako miłośnik czy przyjaciel prawdy (amicus veritatis), pozbawionej często atrybutu uniwersalności czy niezmienności. Mowa w tym przypadku raczej o prawdzie okazującej się zgodnością z własnymi przekonaniami, wiernością wobec głoszonych wartości i poglądów.

Omawiając parezję okupioną pochlebstwem, wspomina Górski o wymagającej dużej zręczności retorycznej umiejętności łączenia nagany z pochwałą, jak w przypadku Cycerona, który krytykując Cezara z powodu jeszcze większej destabilizacji sytuacji społecznej i politycznej w Rzymie, nie skąpił słów uznania dla jego talentu wojskowego. Do strategii parezjastycznych humanista zalicza także pozorną obawę przed przemawianiem. Mówca wie bowiem doskonale, że odbiorcy będą go chętnie słuchać, jak w przytoczonym przykładzie:

[...] cieszyłem się, sędziowie, przyjaźnią z tym człowiekiem, lecz taką przyjaźnią, że chociaż obawiam się, jak przyjmiecie moje słowa, to powiem o tym, czego mnie pozbawiliście. Dlaczego? Gdyż, aby zyskać wasze uznanie, musiałem potraktować kogoś, kto się wam sprzeciwia, raczej jako nieprzyjaciela niż przyjaciela ${ }^{11}$.

11 Ibidem, s. 286-287: „Alteram, qua simulamus nos dicere timere, quod tamen scimus, eos, qui audiunt, libenter audituros, cuius exemplum hoc esse voluit Cornificius: «Mihi cum isto, iudices, fuit amicitia, sed ista tamen amicitia, tametsi vereor quomodo accepturi sitis, tamen dicam, vos me privatis, quid ita? Quam ut vobis esse probatus, eum qui nos oppugnabat inimicum, quam amicum habere malui»". Przykład zapożyczono z Retoryki dla Herenniusza (IV 49). 
W obu tych wypadkach parezja zakłada symulację wymagającą często niemałej pomysłowości mówcy.

Mowa swobodna nie ogranicza się wyłącznie do figury zapowiadającej zmianę sposobu mówienia czy ułatwiającej pozyskanie życzliwości słuchaczy. Rozpatrywana jako schemat językowy przybiera postać powtarzanych w różnych kontekstach, utartych formuł typu: „niech mi będzie wolno powiedzieć o tym otwarcie”, „niech powiem wreszcie, co o tym naprawdę myślę", ,pozwolę sobie powiedzieć o tym szczerze”, ,a teraz nazwę rzeczy po imieniu”, ,powiem o tym bez ogródek, bez zbędnych słów”. Uczyniona ogólną zasadą tworzenia mowy, łączy się z innymi schematami wysłowienia. Występuje na przykład w formie odwrotności aposjopezy (reticentia), figury polegającej na nieoczekiwanym urwaniu przez mówcę wypowiedzi i wymownym zamilknięciu. Jako aposjopeza zaprzeczona (irreticentia) czerpie ona moc perswazyjną z wielokrotnego podkreślania niemożności milczenia, na przykład wobec jawnego naruszenia prawa czy zwyczaju. Może łączyć się z łagodnymi odmianami ironii, zwłaszcza apofazją, czyli długim mówieniem o tym, o czym nie będziemy mówić, i charientyzmem, czyli próbą złagodzenia przykrej prawdy za pomocą odpowiednio dobranych słów. Często pojawia się również $\mathrm{w}$ towarzystwie spokrewnionych $\mathrm{z}$ nią figur myśli związanych $\mathrm{z}$ wyrażeniem albo wzbudzaniem uczuć, na przykład wspomnianego już wykrzyknienia, pytania retorycznego, błagania czy zaklinania kogoś.

Parezja może mieć jeszcze jeden wymiar. Uwagi Kwintyliana dotyczące opozycji między prawdą (naturalnością) a symulacją, wpisane w dyskusję o istocie sztuki wymowy, pozwalają stawiać pytania o granice figuratywności. Strategią charakterystyczną dla figury mowy swobodnej jest bowiem dążenie do wyraźnego ograniczenia albo niemal całkowitej rezygnacji z ozdób retorycznych. Zgodnie z dobrze znaną w dyskursie filozoficznym metaforyką „nagiej” prawdy (ewentualnie „czystej” albo ,jasnej”) nie potrzebuje ona żadnych przebrań językowych, które mogłyby ją zniekształcać albo - co gorsza przesłaniać $^{12}$. Jeśli przyjmujemy, że parezja ma służyć prawdomówności, to powinna się ona zwrócić przeciw samej figuratywności, kwestionując sens tworzenia kolejnych osłon dla tego, co ma być proste, oczywiste. Przywołajmy dwa świadectwa. Przed sądem ateńskiej polis Sokrates zapewnia słuchaczy:

[...] ode mnie usłyszycie całą prawdę. Lecz, na Zeusa, nie będzie to w żadnym razie, mężowie ateńscy, przekazane w takim języku jak ich, pełnym starannie ułożonych zwrotów i określeń, lecz w języku potocznym, w którym określenia pojawiają się bez planu (Apologia) $)^{13}$.

12 Zob. H. Blumenberg, Paradygmaty dla metaforologii, przeł. B. Baran, Warszawa 2017, s. 77-96.

13 Platon, Obrona Sokratesa, przekł. i komentarz R. Legutko, Kraków 2003, s. 21. 
Podobne wyrzeczenie się ornamentów językowych (retoryki) w imię prawdy objawionej zapowiada św. Paweł: ,,ja przyszedłszy do was, bracia, nie przybyłem, aby błyszcząc słowem i mądrością głosić wam świadectwo Boże” (1 Kor 2, 1).

I mędrzec pragnący poznać siebie, i Apostoł Narodów odsłaniający „,tajemnice mądrości Bożej” korzystają z tego samego arsenału retorycznego. Blask słowa może niepotrzebnie zwracać uwagę odbiorców na mowę, a nie samą prawdę, dlatego trzeba zapowiedzieć, że bardzo szybko zostanie zgaszony.

Nawet sprowadzona do prostej, niewyszukanej językowo deklaracji o odrzuceniu ozdób parezja nie przestaje być strategią retoryczną, starannie wcześniej obmyślaną, pełniącą ważną funkcję w perswazji. Rezygnacja z tropów czy figur, o ile w ogóle jest możliwa, nie gwarantuje ex declaratione prawdziwości słów mówcy. Metaforyka „nagiej” prawdy, odartej z niepotrzebnych przebrań językowych, utrwaliła podejrzenia filozofów wobec retoryki. Z jednej strony widzieli oni korzyści płynące z nowych możliwości nazywania i tworzenia pojęć, jakie oferowała sztuka wymowy, z drugiej zaś pozostali nieufni wobec ukrywającego się za nią estetycznego pozoru. Dla wielu z nich parezja mogła być z tego powodu jeszcze jednym, całkiem skutecznym w dłuższej perspektywie sposobem ujarzmiania retorycznego żywiołu, zwłaszcza wtedy, gdy przekonanie o tym, że blask słów nie musi przyćmiewać światła prawdy, nie znajdowało uznania w oczach miłośników mądrości.

W problematyce parezji dochodzą do głosu pytania o istotę figuratywności (retoryki), mechanizm działania tropów i figur, uwikłanie mowy w symulację, ograniczenia wynikające z uwięzienia w wyraźnie zarysowanych przez Kwintyliana dychotomiach: natura - sztuka, spontaniczność - sztuczność, prawda - fałsz. Jako schemat wysłowienia zachowuje ona potencjał krytyczny, jak przypominał Górski, akcentując relacje między mówcą a sposobem tworzenia mowy, przekładającym się na jego kolejne wybory retoryczne, na przykład rezygnację z ornamentów językowych czy dążenie do prostoty i jasności wywodu. Parezja współtworzy „retorykę szczerości”, umożliwiając bardziej swobodne traktowanie reguł dyskursu, żeby można było mówić - albo przynajmniej o tym zapewniać odbiorców - otwarcie, śmiało, odważnie. I nawet jeśli ma ona niewiele wspólnego z nagłym przypływem spontanicznej, naturalnej szczerości, zachowuje moc perswazji płynącą głównie z negocjowania $\mathrm{czy}-\mathrm{w}$ niektórych przypadkach - kwestionowania reguł retorycznych.

W szkołach filozoficznych starożytności przywiązywano o wiele większą wagę do praktyki niż do teorii. Filozofia nie była wówczas wyłącznie domeną abstrakcyjnych spekulacji pozwalających rozwijać spójny system 
uporządkowanych pojęć i twierdzeń o człowieku czy świecie. Stanowiła raczej naukę dobrego (uczciwego) życia, rozmyślanie nad maksymami etycznymi podpowiadającymi wybór drogi prowadzącej do osiągnięcia trwałego szczęścia, uwolnienia od lęku przed śmiercią czy gniewem bogów. Była przede wszystkim, mówiąc słowami Pierre'a Hadota, szeroko rozumianym „ćwiczeniem duchowym" (askesis) ${ }^{14}$, przywracającym wiarę w możliwość zmiany życia i jego swobodnego kształtowania, afirmującym wartość pracy nad samym sobą, sens przekraczania własnych ograniczeń, zmagania się z wadami czy błędami, wreszcie - afirmującym dążenie do nieśmiertelnej sławy. Dystans wobec systematycznego konstruowania teorii i egzegezy kluczowych dla danej formacji filozoficznej tekstów sprzyjał pochwale „sztuki” czy „stylu” życia. Filozofia miała przenikać, a następnie przekształcać całą egzystencję człowieka, aby mógł on odzyskać jasność widzenia świata i siebie, potwierdzić swą wolność, odnaleźć wewnętrzny spokój.

W tym kontekście zupełnie nowego znaczenia nabierała osobista relacja łącząca ucznia z Mistrzem, który rzadko kiedy powierzał nauki pismu, podkreślając tym samym znaczenie żywego słowa, publicznego wykładu i prywatnej rozmowy w przekazywaniu reguł dobrego życia. „Ćwiczenia duchowe” obejmowały uwagę (postawę czujności), słuchanie nauczania, rozmowę, lekturę, medytację, panowanie nad sobą, poskramianie namiętności. W równym stopniu miały angażować intelekt (rozmyślanie), pamięć (zapamiętywanie maksym moralnych), mowę (troska o zgodność języka z myślami oraz odczuciami), wyobraźnię i wrażliwość. Ważną rolę odgrywało tu również kształcenie kompetencji językowych (retorycznych). Umiejętność dialogu (z samym sobą oraz innymi) i pisania pozwalała utrzymywać porządek myślenia. Antyczni mistrzowie nie ukrywali, że filozofia może mieć też znaczenie terapeutyczne, podpowiadając sprawdzone sposoby radzenia sobie z namiętnościami czy obawami.

Istotną wagę do ćwiczeń filozoficznych przywiązywał także w swojej działalności Epikur, który napełnił jeden z ogrodów położonych w pobliżu Aten naukami o życiu szczęśliwym, przyjemności wynikającej z braku cierpienia, daremności lęku przed śmiercią ${ }^{15}$. Miejsce spotkań z uczniami, urzeczywistniające literacki topos „miejsca rozkosznego”, stało się z czasem obrazową antonomazją określającą epikureizm. Jak głosił napis umieszczony przed wejściem: „Gościu, tu ci będzie dobrze, tu gości najwyższe dobro, błoga przyjem-

14 Zob. P. Hadot, Filozofia jako ćwiczenie duchowe, przeł. P. Domański, Warszawa 2003, s. 9-41; idem, Czym jest filozofia starożytna?, przeł. P. Domański, Warszawa 2000, s. 264-291. Zagadnienie „ćwiczeń duchowych” także w: idem, Twierdza wewnętrzna. Wprowadzenie do „Rozmyślań” Marka Aureliusza, przeł. P. Domański, Kęty 2004, s. $45-60$.

15 Zob. A. Krokiewicz, Hedonizm Epikura, Warszawa 1961; K. Pawłowski, Lathe biosas. Żyj w ukryciu. Filozoficzne posłannictwo Epikura z Samos, Lublin 2007. 
ność". Do Ogrodu powracali, chociażby tylko in litteris, wszyscy ci, którzy czerpali inspiracje z nauk Epikura, przekazywanych przez rzesze uczniów i kontynuatorów. Jednym z jego duchowych spadkobierców był Filodemos z Gadary (ok. 110-ok. 40 p.n.e.), poeta (twórca okolicznościowych epigramatów), filozof krzewiący epikurejskie idee w Italii (Kampanii), autor wielu diatryb filozoficznych, traktatów i dialogów, zachowanych w większości do naszych czasów we fragmentach. Wypowiadał się on również na tematy związane z muzyką, sztuką poetycką i retoryczną ${ }^{16}$, ceniąc precyzję wysłowienia i jasność stylu oraz postulując dowartościowanie estetycznego wymiaru retoryki.

Jednym z pism etycznych Filodemosa jest diatryba $O$ wolności stowa

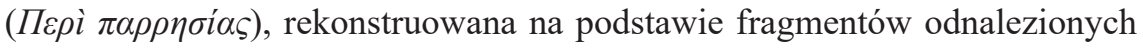
w bibliotece słynnej Willi Papirusów w Herkulanum ${ }^{17}$. Tytułowa parezja oznacza tu przede wszystkim śmiałość w ganieniu błędów, szczerość i otwartość w napominaniu błądzących ${ }^{18}$. I choć wcześniej słowo to funkcjonowało głównie w wymiarze politycznym, wskazując na prawo obywatela ateńskiej polis do swobodnego przemawiania na agorze i wyrażania poglądów, stało się w późniejszej tradycji filozoficznej określeniem cnoty wyróżniającej człowieka. Przekształceniu idei wolności słowa w kategorię etyczną sprzyjało w kręgach epikurejczyków zainteresowanie pielęgnowaniem i rozwijaniem przyjaźni (philia). Według Epikura była ona duchową więzią łączącą ludzi, zrodzoną początkowo z pragnienia korzyści, lecz dojrzewającą stopniowo do bezinteresownej życzliwości czy serdeczności, a także radości ze wspólnego przebywania i dzielenia tych samych poglądów filozoficznych. Miała stanowić podstawę relacji między uczniami, tworzącymi wspólnotę zainteresowaną duchowym, intelektualnym rozwojem ${ }^{19}$. Językiem przyjaźni rządziła parezja, zachęcająca do otwartego mówienia o wadach (swoich i innych) w ramach ćwiczeń przypominających o konieczności pracy nad charakterem.

16 Zob. Filodemos, O muzyce. O utworach poetyckich. Epigramy, przekł., wstęp i przypisy K. Bartol, Warszwa 2002.

17 Willa w Herkulanum (Herculaneum), zasypana popiołami Wezuwiusza (79 r. n.e.), odkryta w trakcie poszukiwań archeologicznych w latach 1752-1754, należała do Kalpurniusza Pizona, miłośnika filozofii i literatury greckiej, opiekuna i przyjaciela Filodemosa. Korzystam z edycji dwujęzycznej: Philodemus, On Frank Criticism, eds. D. Konstan, D. Clay, C.F. Glad, J.C. Thom, J. Ware, Atlanta 1998. Dalej odnotowuję tylko numery odpowiedniego fragmentu.

18 Zob. C.E. Glad, Frank Speech, Flattery, and Friendship in Philodemus [w:] Friendship, Flattery, and Frankness of Speech: Studies on Friendship in the New Testament World, ed. J.T. Fitzgerald, Leiden-New York-Köln 1996, s. 21-60.

19 Zob. J.M. Rist, Epicur on Friendship, „Classical Philology” 1980, no. 2, s. 121-129; K. Pawłowski, Troska o duszę wedtug Epikura z Samos. Epikurejska terapia etyczna według ,Listu do Menojkeusa”, „Kwartalnik Filozoficzny” 2016, nr 1, s. 69-70. 
Diatryba stanowi streszczenie (epitome) wykładów Zenona z Sydonu, na które Filodemos uczęszczał podczas pobytu w Atenach ${ }^{20}$. Dowiadujemy się z nich, że innymi regułami rządzi się parezja w relacji nauczyciel-uczeń, a innymi w wypadku relacji uczeń-uczeń, a także, iż zależy nie tyle od kompetencji pedagogicznych, ile raczej od etycznego rozwoju mistrza, znawcy tajemnic ludzkiej natury, różnych charakterów, sposobów myślenia, pragnień i namiętności. Jako „ćwiczenie duchowe” parezja pozwala rozpoznawać własne słabości i ograniczenia, kształtować umiejętność krytycznego myślenia, włączając w pracę nad sobą również zagadnienia językowe.

Mowa swobodna stanowi rodzaj umiejętności (techne), „sztuki” posługiwania się słowem. Wiąże się ze zbiorem konkretnych reguł, których można się bez większych przeszkód nauczyć, praktykując odpowiednie strategie mówienia. Jak podkreśla Filodemos, służy ona pogłębieniu przyjaźni:

Nawet jeśli wykażemy logicznie, że wiele wspaniałych rzeczy pochodzi z przyjaźni, nie ma niczego ważniejszego od tego, że ma się kogoś, komu można powiedzieć, co mamy w sercu, i kto wysłucha naszej mowy. $Z$ natury pragniemy usilnie odsłonić przed niektórymi ludźmi nasze myśli (fr. 28).

Pielęgnowanie przyjaźni we wspólnocie epikurejskiej powinno prowadzić do odkrywania przyjemności płynącej z choćby chwilowego uwolnienia się od trosk, błędów czy obaw. Można nawet powiedzieć, jak sugeruje Pierre Hadot $^{21}$, że przyjaźn i przyjemność, splecione ze sobą nierozerwalnie za pomocą szczerości, stanowią nowe formy „ćwiczenia duchowego”, wpisane w znacznie szerszy program filozoficzny.

Obustronną relację przyjaźni i przyjemności opisuje mechanizm wzajemnego warunkowania. Według Filodemosa „powinniśmy napominać innych $\mathrm{z}$ dużą śmiałością teraz i także wtedy, gdy niektórzy z nas zostaną następcami naszych nauczycieli i staną się sławni” (fr. 45). Przyjaźń uczy otwartości na innych i wrażliwości na cudze cierpienie, pozwala wyjść poza ciasny krąg własnych myśli, odczuć, przeżyć i doświadczeń. Wymaga dużego opanowania w słowie, niezwykłej kontroli nad językiem, aby szczera $i$ otwarcie przedstawiona krytyka nie zniszczyła zaufania. Parezja zachęca z kolei do ciągłej pracy nad rozwijaniem przyjaźni, ukazuje wartość szczerości i prawdomówności w etycznym doskonaleniu siebie. Wzywa wreszcie do wzajemnej odpowiedzialności za swój rozwój. Postępy w tych ćwiczeniach świadczą o tym, że nieustanna praca nad charakterem, obejmująca możliwość korekty myślenia czy działania, stanowi ważny etap w procesie zdobywania mądrości.

20 Niektóre z zachowanych śródtytułów mają postać konkretnych pytań wskazujących kwestie związane bezpośrednio ze szczerością, przyznawaniem się do błędu, napominaniem innych czy pochlebstwem.

21 P. Hadot, Filozofia jako ćwiczenie duchowe, s. 29-30. 
Filodemos poświęca wiele miejsca napomnieniom dotyczącym nauczyciela. Często pojawia się w nich postać mędrca (sophos) i filozofa prowadzącego działalność pedagogiczną wymagającą etycznej nieskazitelności:

[...] jeśli są jakieś podejrzane rzeczy dotyczące mędrca, a zwłaszcza nauczyciela, powinny zostać wyjaśnione. Jak zamierza on nie znosić kogoś, kto błądzi, nawet nieznacznie, gdy sam wie, że nie jest doskonały, i przypomina wciąż sobie, że każdy zwykł błądzić? (fr. 46).

Rodzaj parezji - to znaczy ostrość krytyki wraz z całą retoryką przyjacielskiego napomnienia - powinien być, zdaniem filozofa, zawsze dostosowany do charakteru ucznia i jego postępów w pracy nad moralną doskonałością. Ta indywidualizacja mowy, przejawiająca się we wprowadzeniu różnych poziomów otwartości i szczerości wypowiedzi, ma stworzyć każdemu (także nauczycielowi) odpowiednie warunki do rozwoju we wspólnocie zjednoczonej wokół wcielania w życie nauk Mistrza z Ogrodu.

Retoryka diatryby filozoficznej dopuszcza swobodne łączenie ze sobą różnych form dyskursywnych: instrukcji, maksymy moralnej, gnomy, napomnienia, krótkiej narracji (na przykład o błędach nauczyciela w młodości), dialogu, cytatu, odwołania się do przykładu Epikura. Parezja, o jakiej pisze Filodemos w kontekście przyjaźni i etyki, obejmuje wielość rozmaitych sposobów mówienia, uzależnionych od mówcy, okoliczności przemowy i adresata. Pozostawia ona dużą swobodę w korzystaniu z narzędzi retorycznych. Dopuszcza użycie zróżnicowanych argumentów logicznych (fr. 1), unikanie fałszywej skromności (fr. 50), uproszczenia języka, zapowiedzi za pomocą odpowiednich formuł, różnych odmian ironii (fr. 26: różnica między napomnieniem a ironią, która się podoba, ale może być za bardzo złośliwa), zmniejszenie bądź zwiększenie siły emocjonalnego zaangażowania (fr. 20).

Filodemos często korzysta z metaforyki medycznej, dobrze zakorzenionej w myśleniu o terapeutycznych właściwościach filozofii. Mówi na przykład o „leczeniu łagodnymi słowami” (fr. 20), o tym, „że jest czymś haniebnym pomagać sobie w leczeniu ciała, lecz nie potrzebować we wszystkim lekarzy, a w przypadku duszy nie starać się słuchać napomnień mędrca" (fr. 30), o nauczycielach „naśladujących lekarzy, którzy leczą także kogoś, kto uważa, że nie wyzdrowieje z tej choroby” (fr. 69), o uczniach „wydających się wyleczonymi nagle i wbrew oczekiwaniom wszystkich" (fr. 32). Jak wynika z tych przytoczonych fragmentów, nauczyciel przypomina lekarza wyczulonego na wszelkie symptomy mogące świadczyć o stanie chorobowym. Jego wiedza o chorobach duszy, wadach, namiętnościach, wsparta długoletnim doświadczeniem pedagogicznym, pomaga w postawieniu szybkiej diagnozy i zleceniu odpowiedniej kuracji, na przykład ćwiczeń z medytacji, dialogu czy parezji, traktowanej jako najlepsze lekarstwo na wszelkie dolegliwości ducha. 
Metaforyka medyczna była zadomowiona w greckiej filozofii. Jej ślady znajdziemy również u Sokratesa (twórcy metody majeutycznej), bohatera dialogów Platona, i u stoików. Chociaż przekształciła się ona z czasem w poręczny zbiór terminów technicznych i mechanicznie powtarzanych analogii, zachowała dużą sugestywność przedstawienia, akcentując wartość krytycznego osądu, rozmowy z chorym, trafnej diagnozy, wyboru odpowiedniego leczenia. Mając w pamięci charakterystyczną dla epikurejskiej askesis troskę o duszę, można powiedzieć, że parezja, umożliwiająca odkrywanie przyjemności płynącej z nauki w gronie przyjaciół, służy przygotowaniu indywidualnej kuracji dla każdego przypadku. Kształtuje ona cnotę pokory i umiarkowania, pozwalając na jednoczesne ujawnienie własnych wad i zganienie błędów innych. Eksponując słabość i ułomność, stanowi paradoksalnie o sile wspólnoty zjednoczonej wokół idei ciągłego wzrastania w przyjaźni dzięki braterskim napomnieniom w duchu wzajemnej życzliwości i serdeczności.

Wątek swobodnego mówienia prawdy przyjaciołom pojawia się również w znanym dialogu Cycerona Leliusz, czyli rozmowa o przyjaźni (Laelius, sive de amicitia), będącym niewyczerpaną skarbnicą argumentów, sentencji i obrazów, powracających w późniejszej literaturze w niezliczonych przebraniach językowych. Jak powiada Leliusz, uosobienie cnót rzymskiego męża stanu:

[...] w rzeczach uczciwych nie mamy czekać, ażby nas proszono, ale z chęcią swą zawżdy mamy być gotowi, nic się nie ociągając. Bezpiecznie też trzeba prawdę mówić przyjacielowi i szczerze radzić. I koniecznie przyjaciół tych, którzy dobrze radzą, trzeba mieć w wielkiej wadze (Laelius XIII, 44)22.

Prawdomówność okazuje się zatem wyznacznikiem prawdziwej (idealnej) przyjaźni, o jakiej rozprawia Leliusz, którego staranne wykształcenie, mądrość, talent retoryczny i długoletnie przywiązanie do Scypiona Afrykańskiego Młodszego, pogromcy Kartaginy, postawiły w rzędzie nie tylko wybitnych polityków i wodzów wojskowych, lecz także sprawdzonych przyjaciół.

Temat szkodliwości pochlebstwa dla rozwoju przyjaźni stał się z kolei przedmiotem rozważań Plutarcha z Cheronei włączonych do tomu pod tytułem Moralia, w których powraca zagadnienie prawdomówności w kontekście miłości samego siebie (philautia). Choć pragnienie afirmacji i pochwały wynika z ludzkiej natury, człowiek potrzebuje konfrontacji z nieprzyjemną niekiedy prawdą o sobie, aby się swobodnie rozwijać. Iluzoryczne wyobrażenia na swój temat mogą rozwiać szczere słowa przyjaciela. Na potrzeby edukacji humanistycznej Erazm z Rotterdamu opracował kompilację cytatów z Moraliów Plutarcha (swoisty katalog similiów), zamykając w jednej ksią-

22 Korzystam z przekładu Bieniasza Budnego: M.T. Cyceron, Księgi o przyjaźni teraz nowo z lacińskiego na polski język z pilnościa przełożone, Drukowano w Wilnie u Jana Karcana, 1603, k. D2. 
żeczce użyteczne maksymy moralne i napomnienia, wyróżniające się dużym potencjałem retorycznym, zwłaszcza niedosłownością i obrazowością (tytułowe parabole). W liście dedykacyjnym adresowanym do przyjaciela, Piotra Aegidiusa (Gilles) z Antwerpii, Erazm z Rotterdamu podkreślał rolę parezji w zwalczaniu fałszywych pochwał:

[...] jeśli ktoś przyzwyczai się już do tego, aby mówić, że pochlebstwo stanowi natychmiastową truciznę dla przyjaźni, to prawdziwym lekarstwem na tę truciznę jest wolność napominania, którą Grecy nazywają parezją. Jeśli skorzystasz wcześniej z tej wolności i tak połączysz ją z pochlebstwem, aby się wydawało, że im bardziej chwalisz przyjaciela, tym bardziej go ganisz, że jest już nieuleczalnie zły, to czy nie okaże się, że nie jest to żadna pochwała jego charakteru? ${ }^{23}$.

Mowa swobodna, o jakiej pisze Erazm, komentując słowa Plutarcha o cnotach parezjasty (stałości, niezłomności, przykładzie własnego życia, nieustępliwości i odwadze), dopuszcza pomysłowe użycie ironii polegającej na prostym odwróceniu znaczeń (nagana w formie pochwały).

W każdym z omówionych powyżej przykładów użycia parezji kładzie się duży akcent na moc sprawczą tego sposobu przemawiania czy terapeutyczne właściwości mowy szczerej, otwarcie głoszącej prawdę bez względu na niesprzyjające okoliczności, różne interesy i zobowiązania, ryzyko niełaski (a nawet śmierci). Za każdym razem chodzi o słowa mogące odmieniać i kształtować ludzkie życie. Wiarę w niezwykłą skuteczność parezji wpisanej w program duchowej metamorfozy podzielał i Filodemos, zainteresowany organizacją wspólnoty uczniów Filozofa z Ogrodu, i Cyceron, nadający postaci doskonałego przyjaciela rysy Leliusza, i wreszcie Erazm, uważny czytelnik Plutarcha, tworzący z myślą o reformie edukacji humanistycznej książkę „miejsc wspólnych”.

\section{III}

Uwaga retorów skupia się przede wszystkim na opisie schematów wysłowienia ukazującym mechanizmy ich działania, uwaga filozofów - na udziale określonej praktyki językowej w doskonaleniu etycznym człowieka. Literatura

23 Erasmus Roterodamus, Parabolae, sive similia postremum ab autore recognita cum accessione nonnulla adiectis aliquot vocularum obscurarum interpretationibus, Parisiis: apud Simonem Colinaeum, 1523, k. A3: „Age iam si quis ad hunc usum accommodet, ut dicat adulationem amicitiae praesentaneum esse venenum, verum ei rursum veneno venenum esse libertatem admonendi, quam Graeci vocant $\pi \alpha \rho \rho \eta \sigma i \alpha v$. Quo si libertatem prius inficias et ita commisceas cum adulatione, ut tum maxime aduleris amico, cum maxime videris obiurgare, iam immedicabile malum esse, nulla ne hic ingenii laus esse videbitur?". 
jako wielkie laboratorium stylu ożywia abstrakcyjne reguły posługiwania się językiem, swobodnie przetwarzając je i przekraczając w kierunku poszukiwania form bardziej pojemnych semantycznie. Stanowi nieustanne ćwiczenie retoryczne, podejmowane niejako na nowo nawet przez tych, którzy wyrzekają się sztuki wymowy w imię pełnej, niemal niczym nieograniczonej wolności inwencji i elokucji. Nie ma w tym niczego dziwnego ani odkrywczego; retoryka spod znaku ,wyjścia poza retorykę” (oznaczającego wejście w ,inną” retorykę) doczekała się już w dziełach antycznych autorów bogatego repertuaru toposów i argumentów.

Odę Horacego adresowaną do Wergiliusza po śmierci wspólnego przyjaciela, Kwintyliusza Warusa, rozpoczyna pytanie dotyczące głównych założeń retorycznych poezji epicedialnej: czy istnieje jakiś umiar (pudor), jakaś granica (modus) w opłakiwaniu ukochanej osoby? (Carmina I 24, 1-2) ${ }^{24}$. W lapidarnej apostrofie poeta przywołuje Melpomenę, lecz nie jako dawczynię natchnienia poetyckiego, ale jako nauczycielkę pieśni żałobnej. Wprowadza dwa tematy, które otrzymają w dalszej części utworu odpowiednie rozwinięcie: pochwałę zmarłego osnutą wokół ukazania wielkości straty i zagadnienie daremności wylewania łez z powodu śmierci, zwłaszcza w kontekście nauk niektórych filozofów, na przykład Epikura i jego uczniów. Poeta występuje od samego początku w roli mistrza sztuki poetyckiej, zainteresowanego o wiele bardziej ekspozycją reguł epicedium za pomocą otwartej gry z literackimi konwencjami niż tworzeniem jeszcze jednej pieśni sławiącej cnoty zmarłego.

Pochodzący z Kremony Kwintyliusz Warus należał do grupy twórców skupionych wokół dworu Oktawiana Augusta. Przyjaźnił się między innymi z Mecenasem, Wergiliuszem i Horacym. Jego nazwisko pojawia się w dedykacji niewielkiej rozprawy Filodemosa o pochlebstwie, co pozwala przypuszczać, że podzielał on założenia filozofii epikurejskiej, znajdującej także wielu orędowników wśród przyjaciół z Rzymu. W scenerii ogrodowej przedstawił go Wergiliusz: „Ciebie, Warusie, nasze tamaryszki, ciebie cały las będzie opiewał” (Ecloga VI 10-11) ${ }^{25}$. Ciekawy portret przyjaciela sporządził Horacy na kartach Sztuki poetyckiej. Ukazał go bowiem jako rzetelnego, uczciwego, śmiałego w swoich sądach, znającego się doskonale na rzeczy krytyka, udzielając mu nawet głosu: „kiedy czytałeś coś Kwintyliuszowi, powiadał: «po-

24 Zob. A. Khan, Horace's Ode to Virgil on the Death of Quintilius: I.24, „Latomus” 1967, vol. 26, s. 107-117; M.C.J. Putnam, The Language of Horace Odes 1.24, „The Classical Journal” 1993, vol. 88, no. 2, s. 123-135; S. Thom, ,, That No Man Lives Forever”: Horace on the Death of Quintilius (1.24), „Akroterion” 1996, vol. 41, s. 114-123; J. Pypłacz, Pięc stadiów żałoby $w$ odzie I. 24 Horacego, „Biuletyn Biblioteki Jagiellońskiej” 2016, nr 66, s. 215-222.

25 O związkach Wergiliusza z epikureizmem zob. G. Davis, Parthenope: The Interplay of Ideas in Vergilian Bucolic, Leiden 2012. 
praw (corrige) to» i «jeszcze» to; a gdybyś się nawet zaklinał, żeś dwa albo trzy razy poprawiał na darmo, kazał skreślić i wiersz niewygładzony wrócić na kowadło" (Ars poetica 438-444).

W pieśni żałobnej wprowadza Horacy orszak alegorycznie przedstawionych cnót, które nie będą teraz mogły znaleźć kogoś, kto mógłby dorównać zmarłemu pod względem moralnej doskonałości. Obok Umiaru (Pudor), Sprawiedliwości (Iustitia) i „nieskazitelnej Wiary” (incorrupta Fides) pojawia się w tym wyliczeniu również „naga Prawda” (nuda Veritas). Jest ona znakiem rozpoznawczym postawy parezjastycznej, wyróżniającej uczciwego krytyka i prawdziwego przyjaciela poetów spośród grona bezkrytycznych pochlebców.

Zgodnie z naukami epikurejczyków żadna pieśń, nawet najbardziej wzruszająca i dopracowana retorycznie, nie przywróci życia „marnym cieniom”, poddanym władzy Merkurego, „Przewodnika dusz” (Psychopompos) na drodze wiodącej w Podziemia. Horacy wydobywa Wergiliusza z niezliczonej rzeszy żałobników pogrążonych w płaczu po śmierci Kwintyliusza, przechodząc nieoczekiwanie od pochwały zmarłego do sławienia poetyckiego talentu przyjaciela. Chociażby - jak powiada Wenuzyjczyk - przewyższył on Orfeusza w sztuce poruszania drzew i dzikich zwierząt, śpiewając jeszcze wdzięczniej, bardziej uwodząco (blandius), nie ożywi zmarłego Warusa. Postać trackiego wieszcza pojawia się tu nie bez powodu. Słowa Wergiliusza umożliwiły mu powrót w mitycznej narracji jako figurze natchnionego poety i niezwykłej mocy poezji (Georgica IV 454-527) ${ }^{26}$. Przywołanie Orfeusza, a tym samym związanego z nim mitu, pełni jednocześnie dwie funkcje. Wspiera argument głoszący daremność lamentów z powodu nieodwracalnej straty, pogrążających tylko w poczuciu niemocy i bezradności, a jednocześnie tworzy starannie opracowaną poetycko pochwałę adresata, daleką od niewyszukanego pochlebstwa.

Pieśń zamyka sentencja, którą można odczytywać jako rodzaj przyjacielskiego napomnienia: choć teraz ciężko (durum), będzie lżej (levius), gdy wytrwałość, cierpliwość (patientia) nauczy nas znoszenia tego, czego nie można (nefas) już w żaden sposób zmienić (corrigere), przywrócić do wcześniejszej świetności, naprawić. Użyte przez Horacego słowo odsyła wprost do działalności Kwintyliusza jako rzetelnego krytyka, który zalecał przyjaciołom, prawdopodobnie także Wergiliuszowi i Horacemu, wprowadzenie konkretnych poprawek. Sytuacja liryczna ulega teraz zmianie. Za pomocą intertekstualnych odniesień poeta pozwala przemówić raz jeszcze Warusowi głosem krytyka, obsadzając go przy tym w roli rzecznika Epikura: o ile można wielokrotnie poprawiać błędy utworu literackiego (na przykład pieśni żałobnej), o tyle nie można skorygować „błędu” śmierci. Epikurejska myśl o daremności lamentu, nazbyt długiego opłakiwania zmarłych nabiera w ten sposób jeszcze

26 Zob. M.O. Lee, Virgil as Orpheus: A Study of the Georgics, New York 1996. 
większej mocy retorycznej. Sam Kwintyliusz zdaje się napominać słowami Horacego cierpiącego z powodu śmierci przyjaciela Wergiliusza, przekonując o potrzebie umiaru i opamiętania, o konieczności zapanowania nad uczuciami.

W kontekście parezji praktykowanej w kręgach literatów skupionych wokół Filodemosa proponuje interpretować tę pieśń Philip Thibodeau ${ }^{27}$. Jednakże różnorodnych odmian mowy swobodnej w liryce Horacego nie można ograniczać wyłącznie do retoryki przyjaźni z napomnieniem czy naganą na czele. Przejawem aktywności parezjastycznej mogą być także liczne realizacje poetyckie motywu odmowy (recusatio), służącego najpełniej afirmacji swobody twórczej i niezależności od literackich poprzedników (na przykład Pindara, Alkajosa czy Safony) oraz panegirycznych zobowiązań, zwłaszcza wobec Oktawiana Augusta i wpływowych członków rodziny cesarskiej ${ }^{28}$. Strategią tej odmowy rządzi często intencja włączenia do pieśni rzeczy pozornie odrzuconych jako jej potencjalny temat (zwycięstwa cesarza, imperialna polityka Rzymu czy imitacja greckich autorów), lecz na zupełnie nowych warunkach, negocjowanych przez poetę $\mathrm{w}$ dialogu $\mathrm{z}$ adresatem utworu.

Oda adresowana do Wergiliusza, ,,połowy mej duszy” (animae dimidium meae, Carmina I 3, 8), jak zapewniał w innej pieśni Horacy, stanowi rodzaj ćwiczenia z parezji, wynikającego z praktycznej realizacji idei głoszonych przez Filodemosa i jego uczniów. Literackie opracowanie tematu mowy swobodnej, a zwłaszcza argumenty przywołujące personifikacje cnót i mitologiczne figury, pogłębia wymowę pieśni wymykającej się sprowadzeniu wyłącznie do poetyckiej ilustracji filozoficznych pouczeń. Zgodnie z retoryką parezji Horacy korzysta z pochwały poety, aby móc powiedzieć mu (a także czytelnikom) znacznie więcej o naturze żałoby oraz poezji epicedialnej. I choć nie są to rzeczy całkowicie nowe czy nieznane, samo ich przypomnienie może mieć wartość terapeutyczną.

W pieśni Macieja Kazimierza Sarbiewskiego, nazywanego nie bez powodu „sarmackim” czy „chrześcijańskim” Horacym, adresowanej do nieznanego bliżej Publiusza Munacjusza ${ }^{29}$, pojawia się zachęta do otwartego, swobodnego mówienia przyjaciołom o swoich troskach i smutkach. O wiele więcej wspólnego ma ona, co zrozumiałe, z dialogiem Cycerona niż diatrybą Filodemosa. Podobnie jak w pieśni Horacego parezja ujawnia się szczególnie wyraźnie w wypowiedziach skierowanych do najbliższych osób. Poeta przekłada

27 Ph. Thibodeau, Can Vergil Cry? Epicureanism in Horace Odes 1.24, „The Classical Journal" 2003, vol. 98, no. 3, s. 243-256.

28 Zob. G. Davis, Polyhymnia: The Rhetoric of Horatian Lyric Discourse, BerkeleyLos Angeles-Oxford 1991, s. 133-143.

${ }_{29}$ W zakończeniu pieśni (w. 28) pojawia się nazwa miejscowości Hall w Tyrolu (Halla), która zachęca do poszukiwań tożsamości konkretnej postaci ukrytej pod imieniem Publiusza Munacjusza. 
konkretne propozycje filozoficzne na język obrazowych figur i sentencji: ,jeśli nasze słowa mogą leczyć rany, pozwól, Publiuszu, przemówić niezagojonej jeszcze ranie i przestań chować w sercu ukryte troski” (Lyrica III 5, 1-4) ${ }^{30}$.

Potężne dęby, jak powiada autor, drąży często ukryty ogień, wzniecony gwałtownym uderzeniem grzmotu; choć stoją teraz dumnie, zachwycając wszystkich rozłożystą koroną, upadają często w jednej chwili, przytłaczając swym ciężarem mniejsze krzewy (Lyrica III 5, 6-11). Dopracowane pod względem retorycznym, rozbudowane porównanie przenosi uwagę czytelnika na sugestywny obraz, a gęsta sieć analogii i podobieństw oplata wypowiedzianą wprost we wcześniejszej strofie zachętę do szczerej rozmowy w gronie przyjaciół.

Parezja rządzi, jak się okazuje, także mówieniem o niej samej. Sarbiewski szybko porzuca nazbyt skomplikowane ozdoby retoryczne: „pożera cię zamiłowanie do długiego milczenia i wrażliwe twoje serce smutek pochłania. Ucieknie o wiele szybciej, kiedy mu każesz nawiedzić uszy przyjaciół i uwolnisz w skardze gniew obfity w słowa" (Lyrica III 5, 11-16) ${ }^{31}$.

Tworzy wrażenie mowy zupełnie swobodnej, płynącej prosto z serca zatroskanego przyjaciela. Nie oznacza ona jednak całkowitego porzucenia wymowy; wiąże się raczej z innym sposobem mówienia, skorelowanym o wiele bardziej z poetyckim przekazem. Językową prostotą, a jednocześnie retorycznym wyrafinowaniem odznaczają się następujące po sobie sentencje:

[...] gdy się skarżymy, skarga często znika, a w czasie płaczu łza wysycha sama [...]. W uszach przyjaciół ból traci swe siły i staje się zawsze mniejszy, gdy się go dzieli, pozwalając mu błądzić $\mathrm{w}$ wielu sercach; wypędzony nie będzie miał odwagi kiedyś powrócić (Lyrica III 5, 17-18, 21-25) ${ }^{32}$.

Sarbiewski dołożył wszelkich starań, aby zachęta do otwartego mówienia o troskach brzmiała szczerze i naturalnie. Przyjacielski ton wypowiedzi, raczej doradzającej niż narzucającej określony sposób myślenia czy działania, współgra z perswazyjnym umiarem i pewną powściągliwością w pouczaniu przyjaciela.

30 M.C. Sarbievius, Lyricorum libri quattuor, epodon liber unus alterque epigrammatum, Antverpiae: ex Officina Plantiniana Balthasaris Moreti, 1634, s. 68: „Si quae iuvabit dicere saucium, / permitte, Publi, compositam male / loqui cicatricem et latentes / parce animo sepelire curas".

31 Ibidem: „Te longus silendi / edit amor facilesque luctus / hausit medullas. Fugerit ocius / simul negantem visere iusseris / aures amicorum et loquacem / questibus evacuaris iram".

32 Ibidem: „Olim querendo desinimus queri / ipsoque fletu lacrima perditur [...]. / Vires amicis perdit in auribus / minorque semper dividitur dolor / per multa permissus vagari / pectora, nec rediisse quondam / pulsus superbit". 
Pieśn do Munacjusza wyróżnia się spośród innych liryków Sarbiewskiego także tematem. W wielu utworach daje się on bowiem poznać jako miłośnik „złotego" milczenia, cnoty mędrca umożliwiającej dystans wobec kłamliwego, rozgadanego tłumu ${ }^{33}$. Jako ważny element fortyfikacji, wzniesionej, aby chronić twierdzę serca (ducha), pozwala ono ukrywać najcenniejsze skarby przed zazdrosnym uchem ludzi. Milczenie może być dla mędrca przystanią, miejscem bezpiecznego schronienia, ale też szkołą charakteru, ćwiczeniem umiarkowania w słowie. $\mathrm{Z}$ nieufnością odnosi się poeta do łez, traktowanych jako wyraz wewnętrznej słabości, objaw bezradności w cierpieniu (Lyrica IV 13). Mogą one świadczyć także o braku umiejętności radzenia sobie z bólem i żalem, zachęcając Fortunę (czy Los) do jeszcze większej śmiałości w doświadczeniu kogoś nieszczęściami. W omawianej pieśni sytuacja liryczna przedstawia się zupełnie inaczej. Pojawia się tu miejsce na swobodne, szczere mówienie w gronie przyjaciół, na skargę, a nawet łzy.

Przedmiotem pieśni etyczno-refleksyjnych Sarbiewskiego jest często duchowy rozwój, poszukiwanie mądrości okazujące się ciągłym poznawaniem siebie, niezwykła podróż do wnętrza duszy, gdzie rozciąga się prawdziwe królestwo mędrca, który ukrywa się niekiedy pod figurą władcy rządzącego sobą czy żeglarza kierującego rozważnie łodzią życia. Grono przyjaciół, o jakim wspomina poeta, stanowi wspólnotę zainteresowaną programem etycznego doskonalenia. Tylko wobec osób podzielających te same ideały filozoficzne parezja może stać się sprawnym narzędziem przywracania równowagi umysłu. Jeśli przyjmiemy, że adresat pieśni stanowi kolejną maskę persony lirycznej, przyjacielskie napomnienie okaże się przypomnieniem samemu sobie sprawdzonego sposobu uśmierzania trosk i gwałtownych afektów (pieśń skierowana do fikcyjnego, a zatem godnego pełnego zaufania adresata); zachęta do szczerego wyznania przybiera dzięki temu postać mowy otwartej, wypowiedzianej ab imo pectore tylko przed samym sobą.

Parezja, mowa swobodna, wyzwolona - przynajmniej teoretycznie - od zewnętrznych uwarunkowań, przybiera w praktyce językowej tak wiele różnych postaci, że nie można jej sprowadzać do zestawu kilku strategii dyskursywnych. Nawet jako figura wysłowienia, zastygająca w często powielanych formułach zapewniających przejście do innego, „bardziej szczerego” sposobu mówienia, projektuje wiązkę rozmaitych wariantów retorycznych. Tylko od pomysłowości mówcy zależy, jaką przybierze ostatecznie postać, pełniąc funkcję niewiele znaczącego ornamentu albo wykraczając daleko poza ramy figury i mając duży udział w kształtowaniu całej mowy. Zawieszenie między tymi dwiema perspektywami, między parezją jako ozdobą stylu a parezją jako ideą wolności mówienia, pozostaje charakterystycznym rysem tej aktywności

33 Zob. E. Buszewicz, Sarmacki Horacy i jego liryka. Imitacja-gatunek-styl. Rzecz o poezji Macieja Kazimierza Sarbiewskiego, Kraków 2006, s. 168-173. 
dyskursywnej. Dochodzą w niej do głosu również problemy istotne z punktu widzenia retoryki, dotyczące natury figuratywności i uzależnienia wymowy od zaplanowanej wcześniej symulacji (udawania).

Mowa otwarta i swobodna pojawia się często w kontekście innych pojęć, tworzących w dodatku różne konstelacje: wolność słowa, charakter mówcy, etyczne zobowiązania, zaangażowanie, szczerość, prawdomówność i prawda, rozumiana jako wierność sobie i głoszonym poglądom. W niektórych szkołach filozoficznych (epikurejczycy, lecz także stoicy i cynicy) przekształca ona prostą strategię retoryczną w ,ćwiczenie duchowe”, wzywając do zaprowadzenia pełnej odpowiedniości między działaniem (myślą) a językiem. Można powiedzieć, że parezja jest szczerością retoryczną, czerpiącą moc perswazyjną z zapowiedzi wprowadzenia nowego sposobu organizacji wypowiedzi albo z odrzucenia, czasem tylko deklaratywnego, nazbyt skomplikowanych tropów i figur. Uwikłana w reguły sztuki wymowy, programy filozoficzne i konwencje literackie, zachowuje niezwykły potencjał krytyczny, pozwalając niekiedy na skuteczne obnażenie iluzji retorycznego gestu.

\section{Bibliografia}

Blumenberg H., Paradygmaty dla metaforologii, przeł. B. Baran, Warszawa 2017.

Buszewicz E., Sarmacki Horacy i jego liryka. Imitacja-gatunek - styl. Rzecz o poezji Macieja Kazimierza Sarbiewskiego, Kraków 2006.

Colclough D., Freedom of Speech in Early Stuart England, Cambridge 2005.

Colclough D., Parrhesia. The Rhetoric of Free Speech in Early Modern England, „Rhetorica” 1999, no. 2.

Cyceron M.T., Księgi o przyjaźni teraz nowo z łacińskiego na polski język z pilnościa przełożone, Drukowano w Wilnie u Jana Karcana, 1603.

Davis G., Parthenope: The Interplay of Ideas in Vergilian Bucolic, Leiden 2012.

Davis G., Polyhymnia: The Rhetoric of Horatian Lyric Discourse, Berkeley-Los Angeles-Oxford 1991.

Dyrberg T., Foucault on the Politics of Parrhesia, New York 2014.

Erasmus Roterodamus, Parabolae, sive similia postremum ab autore recognita cum accessione nonnulla adiectis aliquot vocularum obscurarum interpretationibus, Parisiis: apud Simonem Colinaeum, 1523.

Filodemos, O muzyce, O utworach poetyckich, Epigramy, przekł., wstęp i przypisy K. Bartol, Warszwa 2002.

Foucault M., Fearless Speech, ed. J. Pearson, Los Angeles 2001.

Foucault M., Hermeneutyka podmiotu, przeł. M. Herer, Warszawa 2012.

Foucault M., Le courage de la vérité. Le gouvernement de soi et des autres II. Cours au Collège de France 1984, Paris 2008.

Foucault M., Rzadzenie soba i innymi, przeł. M. Herer, Warszawa 2014. 
Glad C.E., Frank Speech, Flattery, and Friendship in Philodemus [w:] Friendship, Flattery, and Frankness of Speech: Studies on Friendship in the New Testament World, ed. J.T. Fitzgerald, Leiden-New York-Köln 1996.

Gorscius I., De figuris tum grammaticis, tum rhetoricis libri quinque nunc recens aediti, Cracoviae: in officina typographica Matthaei Siebeneycher 1560.

Hadot P., Czym jest filozofia starożytna?, przeł. P. Domański, Warszawa 2000.

Hadot P., Filozofia jako ćwiczenie duchowe, przeł. P. Domański, Warszawa 2003.

Hadot P., Twierdza wewnętrzna. Wprowadzenie do „Rozmyślań” Marka Aureliusza, przeł. P. Domański, Kęty 2004.

Khan A., Horace's Ode to Virgil on the Death of Quintilius: I.24, „Latomus” 1967, vol. 26.

Krokiewicz A., Hedonizm Epikura, Warszawa 1961.

Kwiek M., W strone estetyki egzystencji: Michel Foucault [w:] idem, Dylematy tożsamości. Wokół autowizerunku w powojennej myśli francuskiej, Poznań 1999.

Kwintylian, Institutio oratoria, IX 2, 27 [w:] The Institutio oratoria of Quintilian, ed. H.E. Butler, t. 3, Harvard 1976.

Lausberg H., Retoryka literacka. Podstawy wiedzy o literaturze, przeł. i oprac. A. Gorzkowski, Bydgoszcz 2002.

Lee M.O., Virgil as Orpheus: A Study of the Georgics, New York 1996.

Marrow S.B. SJ, Parrhesia and the New Testament, „Catholic Biblical Quarterly” 1982, vol. 44.

Parkin-Speer D., Freedom of Speech in Sixteenth Century English Literature, „Sixteenth Century Journal" 1981, no. 3.

Pawłowski K., Lathe biosas. Żyj w ukryciu. Filozoficzne posłannictwo Epikura z Samos, Lublin 2007.

Pawłowski K., Troska o duszę wedtug Epikura z Samos. Epikurejska terapia etyczna wedtug ,Listu do Menojkeusa”, „Kwartalnik Filozoficzny” 2016, nr 1.

Philodemus, On Frank Criticism, eds. D. Konstan, D. Clay, C.F. Glad, J.C. Thom, J. Ware, Atlanta 1998.

Platon, Obrona Sokratesa, przekł. i komentarz R. Legutko, Kraków 2003.

Putnam M.C.J., The Language of Horace Odes 1.24, „The Classical Journal” 1993, vol. 88 , no. 2.

Pypłacz J., Pięć stadiów żałoby w odzie I. 24 Horacego, „Biuletyn Biblioteki Jagiellońskiej" 2016, nr 66.

Rist J.M., Epicur on Friendship, „Classical Philology” 1980, no. 2.

Ryczek W., Libertas dicendi. Z genealogii pojęcia parezji, „Teksty Drugie” 2012, nr 3.

Ryczek W., Speaking Freely: Keckermann on the Figure of Parrhesia, „Rhetorica” 2019, no. 2 .

Sarbievius M.C., Lyricorum libri quattuor, epodon liber unus alterque epigrammatum, Antverpiae: ex Officina Plantiniana Balthasaris Moreti, 1634.

Scarpat G., Parrhesia greca, parrhesia cristiana, Brescia 2001.

Scarpat G., Parrhesia. Storia del termine e delle sue traduzione in Latino, Brescia 1964.

Thibodeau Ph., Can Vergil Cry? Epicureanism in Horace Odes 1.24, „The Classical Journal" 2003, vol. 98, no. 3.

Thom S., „, That No Man Lives Forever”: Horace on the Death of Quintilius (1.24), „Akroterion” 1996, vol. 41. 